\title{
School Students' Self-confidence in Science and Intrinsic Motivation for Learning Science: Self-Concept and Self-Efficacy Approach
}

\author{
Palmira Pečiuliauskienė
}

Vytautas Magnus University, K. Donelaičio g. 58, LT-44248 Kaunas, Lithuania, palmira.peciuliauskiene@vdu.lt

\begin{abstract}
The study deals with the Lithuanian school students' self-confidence in science and motivation for learning science on the basis of TIMSS 2015 data. The study analyses two components of self-confidence: science self-concept (SSC) and science self-efficacy (SSE). The research revealed that self-confidence in science of school students statistically significant correlate with the motivation for learning science.
\end{abstract}

Keywords: self-confidence in science, science self-concept, science self-efficacy, intrinsic motivation for learning science.

\section{Introduction}

Over the past decades, the research has demonstrated that the minority of students have motivation for learning science and positive attitudes to science (Osborne, Simon \& Collins, 2003; Byman et al., 2012; Shumow, Schmidt, \& Zaleski, 2013). Improving science, technology, engineering, and math (STEM) education is one of the ways to solve the problem of motivation for learning science. There are different possibilities of improving STEM: an exterior possibility, such as the educational environment and content, and the interior possibility - students' confidence and beliefs about their competence. Scholars have long noticed that students' beliefs about their academic competence play an essential role in their motivation for learning (Bandura, 1997; Zimerman, 2000; Skaalvik, E. M., \& Skaalvik, S., 2004; Myeong, 2018). 
An individual's point of view towards their own characteristics describes the concept of self-confidence (Shavelson, Hubner, \& Stanton, 1976). Analysing the phenomenon of self-confidence in the academic area, scholars distinguish between academic self-concept (Jansen et al., 2014) and academic self-efficacy (Bong \& Skaalvik, 2003; Jansen et al., 2015). Highlighting the phenomenon of self-confidence in the science area, scholars distinguish to two cognitive and emotional processes: evaluation (science self-concept - SSC) and belief (science self-efficacy - SSE) (Chen \& Tutwiler, 2017). Learners' self-efficacy beliefs are closely related to motivating themselves (Bandura, 1997). Scholars define learning motivation as a tendency for students to benefit from meaningful learning activities (Wlodkowski, 1999). Motivation refers to the reason for a specific action in short and long terms and presents a sense of direction (vector) and its continuation (Kim, 2004). Intrinsic motivation refers to doing something because it is inherently interesting or enjoyable. A motivational activity aims at inspiring self-confidence and takes a sense of satisfaction with the results of successful learning tasks (Keller, 1987; Shin, 2018). Motivation for learning depends on a student's expectations for success and self-related beliefs, as well as on values associated with a particular task (Pintrich, 2003).

International Science and Mathematics Study (TIMSS) instruments are designed to measure self-confidence and motivation of school students. Scholars have revealed a positive correlation between science achievements and attitudes towards science on the basis of TIMSS 2011 data (Akili, 2015; Ng et al., 2012), as well as between affective factors and science and mathematics achievements on the basis of TIMSS 2007 (Lay et al., 2015). However, scholars have rarely investigated how self-confidence in science of school students is related to intrinsic motivation for learning science.

In view of this, the purpose of the article is to analyze the relationship between the self-confidence of school students in science and their intrinsic motivation for learning science on the basis of TIMSS 2015 data.

\section{Theoretical background}

There may be different theoretical approaches to students' motivation for learning and self-confidence. One of them is the socio-cognitive view, which emphasizes the cognitive and emotional process. Expectancy-Value Theory (EVT), which states that the motivation of students' behaviour comes from the combination of their needs and the value of the goals, gives the theoretical background of the socio-cognitive view (Eccles et al., 1983; Wigfield, \& Eccles, 2000; Trautwein et al., 2012). According to EVT, students' motivation for learning is determined by two factors: expectancies for success and subjective task values (Figure 1). Expectancies for success refer to how confident a student is in his or her ability to succeed in a task in the short-term future or long-term future, whereas task values refer to how important the student perceives the task. Expectancies and task values 
interact to predict the main outcomes of education, such as motivation and academic achievement (Nagengast et al., 2011; Trautwein et al., 2012).

According to EVT, the expectation of learners for success in science depends on self-confidence in science (Figure 1). This construct is an important point of reference in psychological theories of motivation (Eccles, 2009; Sheldrake, 2016). Bandura (1994) states that "People with high assurance in their capabilities approach difficult tasks as challenges to be mastered rather than as threats to be avoided" (Bandura, 1994, 2). Meanwhile, the people who doubt their capabilities "dwell on their personal deficiencies, on the obstacles they will encounter, and all kinds of adverse outcomes rather than concentrate on how to perform successfully" (Bandura, 1994, 2). Self-confidence has a practical topicality to education because students' self-confidence is associated with their motivation in particular subjects (Viljaranta, Tolvanen, Aunola, \& Nurmi, 2014).

The phenomenon of self-confidence can be expanded according to various fields of activity. Self-confidence appears to be beneficial within the academic area (science, social science and so on) (Sheldrake, 2016). Academic self-confidence reveals as academic self-concept (Jansen et al., 2014) and academic self-efficacy (Bong \& Skaalvik, 2003; Jansen et al., 2015). Scholars conceptualize academic self-confidence to particular academic subjects (Bong \& Skaalvik, 2003). According to this conceptualization, students' self-confidence in science consists of science self-concept (SSC) and science self-efficacy (SSE) (Sheldrake, 2016).

Self-confidence in a science construct can be expanded according to the time line: past, present, and future (Figure 1). Science self-concept describes self-confidence based on past experiences (integrating historical experiences), whereas science self-confidence at present (Sheldrake, 2016). Meanwhile, science self-efficacy is based on self-confidence for future attainment (Figure 1). "Self-efficacy considers someone's evaluative beliefs about their future capacities, such as their confidence in being able to gain a particular examination grade or to successfully accomplish a particular type of exercise" (Sheldrake, 2016, 51).

Students' self-concept has been theorized by three kinds of the sources of self-concept: temporal (self-comparisons over time), social (self-comparisons with other students), dimensional (self-comparisons across subjects) (Moller \& Marsh, 2013; Marsh \& Craven, 2006). Some researchers have explored SSC temporal comparison. They reveal that students' SSC "expressed as subjective beliefs of 'doing well' or 'being good' at science was most strongly predicted by received praise, current grades, and interest in science" (Sheldrake, 2016, 63). However, there is a lack of research on SSC and subjective task value, on SSC and motivation for learning science. 


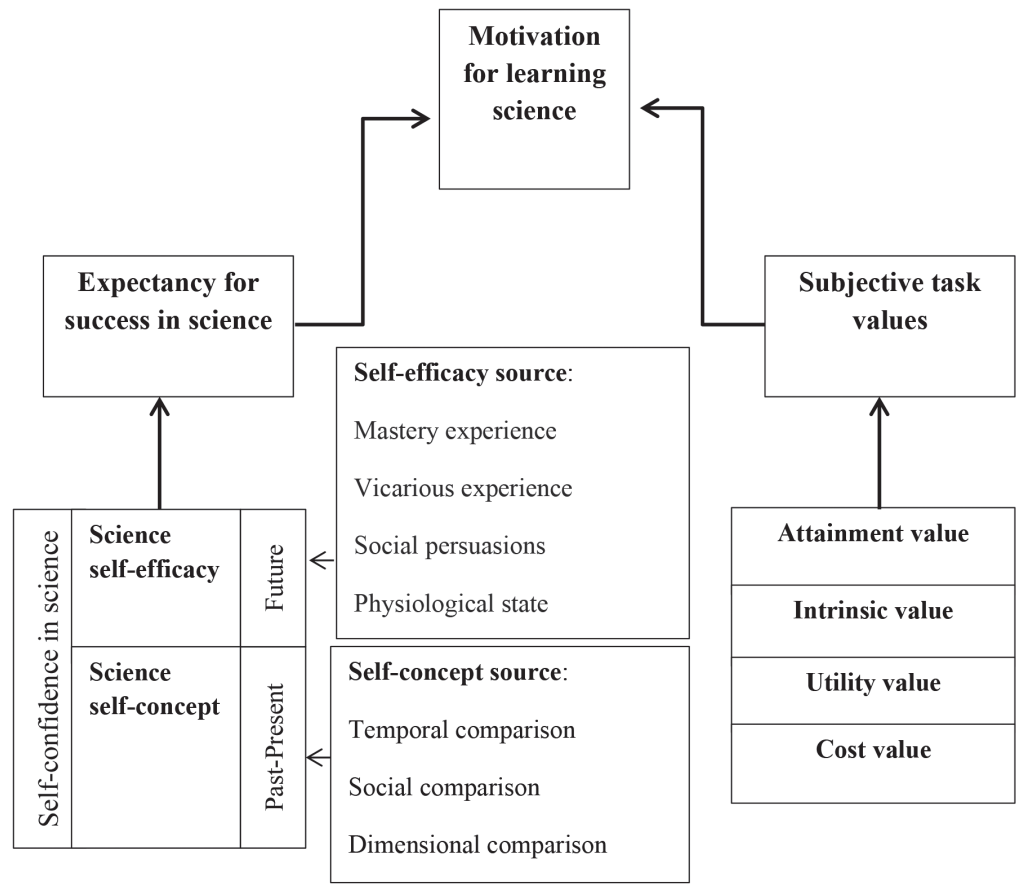

Figure 1. Motivation for learning science and self-confidence in science: Expectancy-Value Theory approach

The concept of self-efficacy should not be overlooked when analysing learning motivation (Bøe, \& Henriksen, 2015; Shin, 2018). According to EVT, self-efficacy is an integral part of self-confidence (Figure 1). "Self-efficacy is defined as people's beliefs about their capabilities to produce designated levels of performance that exercise influence over events that affect their lives" (Bandura, 1994, 2). Psychologists reveal four sources of self-efficacy: mastery experience (experience in overcoming obstacles), vicarious experience (result from the observation of models how peers perform certain tasks), social persuasions (encouragement from peers and teachers), and physiological state (perceived stress or anxiety when solving a task) (Bandura,1994; Pajares, 1994; Usher \& Pajares, 2009) (Fgure 1).

According to EVT, students' engagement and interest in science is influenced not only by SSC and SSE, but also by subjective task values (Figure 1). A subjective task value can be thought of the motivation that allows an individual to answer the question about the meaningfulness of the activity (Ecceles et al., 1983). Subjective task-related values have been categorized as the attainment value (importance or significance for identity or self), the intrinsic value (enjoyment and interest), the utility value (instrumental benefit 
or usefulness), and the costs of engaging in the task (loss of time, high effort demands, negative psychological experiences) (Eccles et al., 1983) (Figure 1).

\section{Method of research}

SCS and motivation for learning science were analysed on the basis of EVT. TIMSS 2015 data of eighth grade students from Lithuania were used $(\mathrm{N}=4347)$. The data were used from the TIMSS 2015 database (http://www.timss.org/).

The Students Confident in Science scale measures SCS of students. The Students Confident in Science scale consists of three subscales: the Students Confident in Chemistry scale (SCC), the Students Confident in Biology scale (SCB), and the Students Confident in Physics scale (SCP). The variables of Students Confident in Science scale measure both components of SCS: (SSC) and (SSE).

The results of Cronbach's alpha ( $\alpha$ ) of Students Confident in Science scale are tolerable: SCC scale - 0.87; SBC scale - 0.85; SCP scale - 0.86 . The data of the scale variables (SCB; SCC; SCP) were well within a tolerable range for assuming a normal distribution.

Students Like Learning Science (SLL) takes a possibility to analyse the underlying construct - motivation for learning science in TIMSS 2015 research. SLL scale consists of three subscales: Students Like Learning Biology (SLB) scale, Students Like Learning Chemistry (SLC) scale, and Students Like Learning Physics (SLP) scale.

EFA was carried out in order to exclude variables related to students' motivation for learning science. Reliability analysis of the factorability of SLL science scale of the students from Lithuania was provided on the basis of Cronbach's alpha ( $\alpha$ ). It was surprising that all alpha values were the same: SLC scale - 0.92; SLC scale - 0.92; SLP scale - 0.92 (Martin, et al., 2016). In the application of EFA, it has been taken into account that skewness (from -1 to +1 ) and kurtosis (from -1 to +1 ) of the scale variables (SLB; SLC; SLP) were well within the requirement of a normal distribution.

\section{Results}

The secondary data analysis of TIMSS 2015 was performed according to the theoretical model of EVT (Figure 1). The expectancy for success in science depends on SSC and SSE of students. TIMSS 2015 instrument for students' confidence in science allowed carrying out an empirical analysis of both components of self-confidence in science: SSC and SSE.

Eight variables related to students' self-concept and self-efficacy of different science subjects (biology, chemistry, physics) were factor analysed using the exploratory factor analysis (EFA) (Table 1). Factorability of students' self-confidence in biology was examined by measures of sampling adequacy. The Kaiser-Meyer-Olkin test (KMO-test) 
revealed sampling adequacy. It was disclosed $\mathrm{KMO}=0.859<.05$ for observed variables. The inter correlation was checked by using Bartlett's test $\left(\chi^{2}(28)=14981.772, p<.05\right)$. All the elements on the diagonal (MSA- Measure of Sampling Adequacy) of anti-image correlation matrix were greater than 0.5 . Extraction communalities indicate that the variables chosen for this analysis were related to each other (Table 1).

Table 1

Factor analysis of students' self-confidence in science (biology, chemistry, physics): the issue of Students Confident in Science scale

\begin{tabular}{|c|c|c|c|}
\hline \multirow[b]{2}{*}{ Items of SCB; SCC; SCP scale } & \multicolumn{3}{|c|}{ Loadings } \\
\hline & $\begin{array}{c}\text { Factor } 1 \\
\text { Temporal } \\
\text { comparison / } \\
\text { Social } \\
\text { persuasion }\end{array}$ & $\begin{array}{c}\text { Factor } 2 \\
\text { Dimensional } \\
\text { comparison / } \\
\text { Physiological } \\
\text { state }\end{array}$ & $\begin{array}{c}\text { Commu- } \\
\text { nalities }\end{array}$ \\
\hline $\begin{array}{l}\text { I am good working out difficult biology } \\
\text { problems }\end{array}$ & .847 & -.171 & .678 \\
\hline My teacher tells me I am good at biology & .827 & -.038 & .677 \\
\hline I learn things quickly in biology & .817 & -.269 & .652 \\
\hline I usually do well biology & .760 & -.317 & .741 \\
\hline $\begin{array}{l}\text { Biology is harder form me than any other } \\
\text { subject }\end{array}$ & -.147 & .842 & .746 \\
\hline Biology is more difficult for me & -.189 & .801 & .686 \\
\hline Biology make me confused & -.102 & .766 & .730 \\
\hline Biology is not of my strength & -.297 & .750 & .597 \\
\hline Eigenvalue & 3.966 & 1.539 & \\
\hline$\%$ of Total Variance & 49.581 & 19.242 & \\
\hline Total Variance & $68.823 \%$ & & \\
\hline I am good working out difficult chemistry & .881 & -.149 & .744 \\
\hline problems & .859 & -.220 & .690 \\
\hline My teacher tells me I am good at chemistry & .853 & -.133 & .690 \\
\hline I learn things quickly in chemistry & .805 & -.310 & .787 \\
\hline I usually do well chemistry & -.164 & .815 & .799 \\
\hline Chemistry is harder form me than any other & -.221 & .801 & .745 \\
\hline subject & -.285 & .780 & .690 \\
\hline Chemistry is more difficult for me & -.091 & .756 & .580 \\
\hline Chemistry make me confused & & & \\
\hline Chemistry is not of my strength & & & \\
\hline Eigenvalue & 4.162 & 1.562 & \\
\hline$\%$ of Total Variance & 52.029 & 19.529 & \\
\hline Total Variance & $71.558 \%$ & & \\
\hline
\end{tabular}




\begin{tabular}{llll}
\hline I am good working out difficult physics & $\mathbf{. 8 7 9}$ & -.132 & .761 \\
problems & $\mathbf{. 8 5 9}$ & -.121 & .682 \\
My teacher tells me I am good at physics & $\mathbf{. 8 5 4}$ & -.213 & .670 \\
I learn things quickly in physics & $\mathbf{. 8 3 0}$ & -.268 & .775 \\
I usually do well physics & -.146 & $\mathbf{. 8 1 6}$ & .789 \\
Physics is harder form me than any other & -.236 & .791 & .752 \\
subject & -.257 & .777 & .688 \\
Physics is more difficult for me & -.059 & .756 & .576 \\
Physics is not of my strength & & & \\
Physics make me confused & & & \\
\hline Eigenvalue & 4.043 & 1.650 & \\
\% of Total Variance & 50.538 & 20.622 & \\
Total Variance & $71.160 \%$ & & \\
\hline
\end{tabular}

The rotation method Varimax was used for simplification of factors interpretation in PCA. The principal component analysis (PCA) of school students' confidence in biology yielded into two factors explaining a total of $68.823 \%$ of the variance for the entire set of variables. Factor 1 was labelled Temporal comparison/Social persuasion due to the high loadings by the following items: good at working out difficult problems; good at biology; learn quickly in biology; and usually do well in biology. The first factor explained $49.581 \%$ of the variance. The second factor derived was labelled Dimensional comparison/Physiological state. This factor was labelled as such due to the high loadings by the following factors: biology is harder for me; biology is more difficult for me; biology makes me confused; biology is not a strength of mine. The variance explained by this factor was $19.242 \%$ (Table 1). This means that we have identified two clear patterns of response - the pattern Temporal comparison/Social persuasion and the pattern Dimensional comparison/Physiological state. These two tendencies are independent of one another (i.e. they are not correlated).

Factorability of students' self-confidence in chemistry was also examined. The Kaiser-Meyer-Olkin test (KMO-test) revealed sampling adequacy for students' confidence in chemistry $(\mathrm{KMO}=0.869<.05)$. The inter correlation was checked by using Bartlett's test of confidence in chemistry $\left(\chi^{2}(28)=17274.372, p<.05\right)$. All the elements on the diagonal (MSA- Measure of Sampling Adequacy) of anti-image correlation matrix were greater than 0.5. PCA of SCC scale variables revealed two factors: Factor 1 (Temporal comparison/ Social persuasion) and Factor 2 (Dimensional comparison/Physiological state) (Table 1).

Students' self-confidence in physics was analysed using EFA. The Kaiser-Meyer-Olkin test (KMO-test) revealed sampling adequacy for students' confidence in physics $(\mathrm{KMO}=0.862<.05)$. Bartlett's test of students' self-confidence in physics $\left(\chi^{2}(28)=16829.662, p<.05\right)$. All the elements on the diagonal (MSA- Measure of Sampling Adequacy) of anti-image correlation matrix of self-confidence in physics were greater than 0.5. PCA of SCP scale variables also revealed two factors (Table 1). 
On the basis of the data of Students Confident in Science scale, EFA revealed a clearcut model of students' self-confidence in science: Factor 1 - Temporal comparison/Social persuasion and Factor 2 - Dimensional comparison/Physiological state. Both factors are well defined and internally consistent (Table 1 ). The $1^{\text {st }}$ factor encompasses four variables of positive character: "I am good at working out difficult science problems"; "My teacher tells me I am good at science"; "I learn things quickly in science"; "I usually do well in science". The three variables of the factor Self-Confident in science are based on SSC temporal comparison and express the self-concept of students that they can generally accomplish science tasks. Students compare their performance in one subject for a long time: "I am good at working out", "I learn things quickly", and "I usually do well". The variable "My teacher tells me I am good at biology" expresses the encouragement of a teacher, which enhances students' self- confidence in subject. This variable describes social persuasions and is a theoretically justified source of self-efficacy.

\section{Students' motivation for learning science}

Nine questions related to students' motivation for learning science (biology, chemistry, physics) were analysed using EFA principal component analysis with Varimax rotation (Table 2) on the basis of the data of TIMSS 2015. The Kaiser-Meyer-Olkin test (KMO-test) was used for sampling adequacy. It was disclosed that for SLB scale (KMO = .917<.05), for SLC scale $(\mathrm{KMO}=.916<.05)$, and for SLP scale $(\mathrm{KMO}=.909<.05) \mathrm{KMO}$ confirmed the sampling adequacy. The inter-correlation of the variables was detected with Bartlett's test: for SLB scale $\left(\chi^{2}(36)=24203.771, p<.05\right)$; for SLC $\left(\chi^{2}(36)=26722.306, p<.05\right)$ scale, and for SLP scale $\left(\chi^{2}(36)=26223.732, p<.05\right)$.

All the elements on the diagonal (MSA - Measure of Sampling Adequacy) of anti-image correlation matrix were greater than 0.5 . Extraction communalities indicated that the variables chosen for this analysis were related to each other on scales: SLB; SLC; and SLP.

The rotation method Varimax was used for simplification of factors interpretation in PCA. PCA of school students' motivation for learning science (biology, chemistry, physics) yielded two factors (Table 2). The variables of the $1^{\text {st }}$ and $2^{\text {nd }}$ factors are similar for all subjects: biology, chemistry, and physics. However, the variable weights of the factors are different for different subjects (Table 2). 
Table 2

Factor analysis of students' motivation for learning science (biology, chemistry, physics): the issue of Students Like Learning Science scale

\begin{tabular}{|c|c|c|c|}
\hline \multirow[b]{2}{*}{ Items of SLB; SLC; SLP scale } & \multicolumn{3}{|c|}{ Loadings } \\
\hline & $\begin{array}{c}\text { Factor } 1 \\
\text { Intrinsic moti- } \\
\text { vation for lear- } \\
\text { ning science }\end{array}$ & $\begin{array}{c}\text { Factor } 2 \\
\text { Amotivation } \\
\text { for learning } \\
\text { science }\end{array}$ & $\begin{array}{c}\text { Commu- } \\
\text { nalities }\end{array}$ \\
\hline Biology teachers me how things in the world work & .790 & .107 & .748 \\
\hline I learn many interesting things in biology & .784 & .275 & .777 \\
\hline I like biology & .763 & .494 & .768 \\
\hline I like to conduct biology experiments & .759 & .061 & .690 \\
\hline I enjoy learning biology & .731 & .462 & .827 \\
\hline I look forward for learning biology in school & .708 & .444 & .698 \\
\hline Biology is one of my favorite & .699 & .446 & .636 \\
\hline I wish did not have to study the biology & -.151 & -.869 & .580 \\
\hline Biology is boring & -.262 & -.836 & .688 \\
\hline Eigenvalue & 5.398 & 1.014 & \\
\hline$\%$ of Total Variance & 59.977 & 11.269 & \\
\hline Total Variance & $71.246 \%$ & & \\
\hline I like chemistry & .836 & .370 & .785 \\
\hline Chemistry is one of my favorite & .815 & .324 & .818 \\
\hline I learn many interesting things in chemistry & .813 & .215 & .789 \\
\hline I enjoy learning chemistry & .811 & .357 & .707 \\
\hline I look forward for learning chemistry in school & .799 & .308 & .836 \\
\hline $\begin{array}{l}\text { Chemistry teachers me how things in the world } \\
\text { work }\end{array}$ & .768 & .118 & .734 \\
\hline I like to conduct chemistry experiments & .718 & .086 & .604 \\
\hline I wish did not have to study the chemistry & -.187 & -.885 & .523 \\
\hline Chemistry is boring & -.272 & -.846 & .769 \\
\hline Eigenvalue & 5.501 & 1.063 & \\
\hline$\%$ of Total Variance & 61.121 & 11.815 & \\
\hline Total Variance & 72.936 & & \\
\hline I like physic & .840 & -.341 & .772 \\
\hline I learn many interesting things in physics & .816 & -.192 & .818 \\
\hline I enjoy learning physics & .811 & -.339 & .790 \\
\hline Physics is one of my favorite & .797 & -.313 & .702 \\
\hline I look forward for learning physics in school & .787 & -.276 & .822 \\
\hline Physics teachers me how things in the world work & .778 & -.093 & .696 \\
\hline I like to conduct physics experiments & .770 & -.103 & .614 \\
\hline I wish did not have to study the physics & -.172 & .888 & .604 \\
\hline Physics is boring & -.266 & .848 & .733 \\
\hline Eigenvalue & 5.432 & 1.119 & \\
\hline$\%$ of Total Variance & 60.357 & 12.437 & \\
\hline Total Variance & $72.794 \%$ & & \\
\hline
\end{tabular}


According to SDT, the $1^{\text {st }}$ factor was labelled Intrinsic Motivation for Learning Science due to the high loadings by the following items: "I enjoy learning the subject"; "I learn many interesting things in the subject"; "I like the subject"; "I look forward to learning the subject at school"; "The subject teaches me how things in the world work"; "I like to conduct subject experiments"; "The subject is one of my favourite". The items ("I like", "I enjoy", "My favourite", "I learn many interesting things") correspond to intrinsic motivation. The items of the $1^{\text {st }}$ factor have interest value. "Interest value is a construct similar to the construct of intrinsic motivation $\langle\ldots\rangle$ because it concerns doing a task out of interest and enjoyment" (Wigfield and Ecceles, 2000, 73).

The $2^{\text {nd }}$ factor was named Amotivation for Learning Science. Amotivation is the first type of motivation and occurs when a student has very low levels of motivation towards science subject: I wish did not have to study the subject; The subject is boring (Table 2).

Students Like Learning Science (LLS) scale revealed group variables corresponding to intrinsic motivation for learning science (Factor 1) (Table 2). As it was mention earlier, this group of variables does not depend on the subject: biology, chemistry, and physics.

\section{Correlational analysis of self-confidence of school students in science and their intrinsic motivation for learning science}

To elucidate the relationship between students' intrinsic motivation for learning science and their self-confidence in science, the Spearman correlation was used. The motivation for learning science and confidence in science were measured by ordinal scales in TIMSS 2015 research. In this case, Spearman correlation is useful.

A strong statistically significant correlation was found between all the variables of the factor named Intrinsic Motivation for Learning Science and all the variables of the factor Self-Confident in Science (Table 3). The same tendency was found in the analysis of the correlation between intrinsic motivation for learning physics and self-confidence in physics, intrinsic motivation for learning chemistry, and self-confidence in chemistry, as well as intrinsic motivation for learning biology and self-confidence in biology.

The correlational analysis revealed that correlation coefficients between SSE (social persuasions) and motivation variables are lower. Spearman correlation coefficients between SSC (temporal comparison) variables and motivation variables are higher (Table 3), and this tendency does not depend on science subject (physics/biology/chemistry) (Table 3).

The lowest correlation coefficient values were identified between SSE variable "The teacher tells I am good at physics/biology/chemistry" and motivation variable "Physics/ Biology/Chemistry teaches me how things in the world work" $\left(\mathrm{r}_{\mathrm{s}}=.395, \mathrm{p}<.001 ; \mathrm{r}_{\mathrm{s}}=.327\right.$, $\left.\mathrm{p}<.001 ; \mathrm{r}_{\mathrm{s}}=.435, \mathrm{p}<.001\right)$. It is important to note that the variable "Physics/Biology/ Chemistry teaches me how things in the world work" expresses an action from outside. The motivation variables that express an action from the student's initiative ("I learn", "I look forward to") or a positive emotion ("I enjoy", "I like") has a stronger correlation with variables of self-confidence in science (Table 3). 
Table 3

Spearman correlation between intrinsic motivation variables for learning science and self-confidence in science

\begin{tabular}{|c|c|c|c|c|}
\hline \multirow{3}{*}{ Motivation variables } & \multicolumn{4}{|c|}{ Self-Confidence in science } \\
\hline & \multirow{2}{*}{$\begin{array}{c}\begin{array}{c}\text { SSE (social } \\
\text { persuasions) }\end{array} \\
\text { Teacher tells: } \\
\text { I am good at } \\
\text { science }\end{array}$} & \multicolumn{3}{|c|}{ SSC (temporal comparison) } \\
\hline & & $\begin{array}{c}\text { I am good at } \\
\text { working out } \\
\text { problems }\end{array}$ & $\begin{array}{l}\text { I learn } \\
\text { things } \\
\text { quickly }\end{array}$ & $\begin{array}{l}\text { I usu- } \\
\text { ally do } \\
\text { well }\end{array}$ \\
\hline I enjoy learning physics & $.551^{* *}$ & $.590^{* *}$ & $.617^{* *}$ & $.665^{\star *}$ \\
\hline I learn many interesting things in physics & $.445^{* *}$ & $.451^{* *}$ & $.500^{* *}$ & $.506^{* *}$ \\
\hline I like physics & $.553^{* *}$ & $.591^{* *}$ & $.614^{* *}$ & $.641^{\star *}$ \\
\hline I look forward to learning physics & $.542^{* *}$ & $.571^{* *}$ & $.566^{* *}$ & $.583^{\star *}$ \\
\hline $\begin{array}{l}\text { Physics teaches me how things in the world } \\
\text { work }\end{array}$ & $.395^{* *}$ & $.396^{* *}$ & $.428^{* *}$ & $.434^{\star *}$ \\
\hline Physics is one of my favourite subjects & $.569^{* *}$ & $.608^{* *}$ & $.606^{* *}$ & $.627^{\star *}$ \\
\hline I like to conduct physics experiments & $.394^{* *}$ & $.404^{* *}$ & $.450^{* *}$ & $.435^{* *}$ \\
\hline I enjoy learning biology & $.464^{* *}$ & $.532^{* *}$ & $.581^{\star *}$ & $.576^{\star *}$ \\
\hline I learn many interesting things in biology & $.366^{* *}$ & $.408^{* *}$ & $.492^{\star *}$ & $.453^{\star *}$ \\
\hline I like physics & $.457^{* *}$ & $.513^{* *}$ & $.568^{\star *}$ & $.550^{\star *}$ \\
\hline I look forward to learning biology & $.467^{* *}$ & $.487^{* *}$ & $.512^{* *}$ & $.486^{* *}$ \\
\hline $\begin{array}{l}\text { Biology teaches me how things in the } \\
\text { world work }\end{array}$ & $.327^{* *}$ & $.353^{* *}$ & $.415^{\star *}$ & $.412^{* *}$ \\
\hline Biology is one of my favourite subjects & $.469^{* *}$ & $.523^{* *}$ & $.540^{\star *}$ & $.518^{* *}$ \\
\hline I like to conduct biology experiments & $.339^{* *}$ & $.361^{* *}$ & $.394^{* *}$ & $.362^{* *}$ \\
\hline I enjoy learning chemistry & $.554^{\star *}$ & $.591^{\star *}$ & $.631^{\star *}$ & $.678^{\star *}$ \\
\hline I learn many interesting things in chemistry & $.450^{* *}$ & $.459^{* *}$ & $.522^{\star *}$ & $.530^{* *}$ \\
\hline I like chemistry & $.554^{* *}$ & $.596^{\star *}$ & $.627^{\star *}$ & $.661^{* *}$ \\
\hline I look forward to learning chemistry & $.544^{\star *}$ & $.583^{\star *}$ & $.602^{\star *}$ & $.598^{\star *}$ \\
\hline $\begin{array}{l}\text { Chemistry teaches me how things in the } \\
\text { world work }\end{array}$ & $.435^{\star *}$ & $.416^{\star *}$ & $.462^{\star *}$ & $.464^{* *}$ \\
\hline Chemistry is one of my favourite subjects & $.574^{* *}$ & $.604^{\star *}$ & $.642^{* *}$ & $.637^{\star *}$ \\
\hline I like to conduct chemistry experiments & $.347^{* *}$ & $.341^{\star \star}$ & $.400^{\star *}$ & $.412^{\star *}$ \\
\hline
\end{tabular}

The lowest correlation coefficient values were also detected between SSE variable "The teacher tells I am good at physics/biology/chemistry" and motivation variable "I like to conduct physics/biology/chemistry experiments" $\left(\mathrm{r}_{\mathrm{s}}=.394, \mathrm{p}<.001 ; \mathrm{r}_{\mathrm{s}}=.339, \mathrm{p}<.001\right.$; $\left.\mathrm{r}_{\mathrm{s}}=.347, \mathrm{p}<.001\right)$. It can be maintained that social persuasions are not effective for fostering motivation for learning science in science experimental activity.

The research performed on the basis of TIMSS 2015 data from Lithuania allows maintaining that individual and positive feedback are effective ways to foster SSE and motivation for learning. The statistically significant correlation coefficient values have 
been set between SSE variable “The teacher tells I am good at physics/biology/chemistry", and all motivation variables (Table 3 ). The lowest correlation coefficient value is $r_{s}=.327$, $\mathrm{p}<.001$; the highest $-\mathrm{r}_{\mathrm{s}}=.574^{* *}, \mathrm{p}<.001$. The social persuasion variable "The teacher tells I am good at physics/biology/chemistry" expresses a positive and individual feedback provided by teachers for students.

\section{Discussion}

The present study examines the self-confidence in science and intrinsic motivation for learning science of school students from Lithuania from the approach of science self-concept and science self-efficacy sources. The EFA analysis was adopted to examine the self-confidence in science and motivation for learnings science on the basis of TIMSS 2015 data of eighth grade students from Lithuania.

The relevance of our study is deduced from previous studies: "Self-concept and selfefficacy are two of the most important motivational predictors of educational outcomes" (Jansen, 2015, 13). The phenomenons of self-concept and self-efficacy are analysed in various academic areas. There is evidence that academic self-confidence is caused by motivational constructs: goal orientations, persistence, task choices, and career aspirations (Pajares et al., 2000; Parker et al., 2014). Scholars analyse how academic self-concept and academic self-efficacy (ASE) predict educational outcomes. Moreover, there is evidence that ASC should influence affective reactions, course choices, and educational aspirations (Nagengast \& Marsh, 2012).

We analysed the phenomena of self-concept and self-efficacy in the science area. Our purpose was to analyse the self-confidence of school students in science and to reveal the relationship between self-confidence in science and intrinsic motivation variables for learning science. According to the theoretical model EVT for learning science formed in the study, motivation for learning science depends on a student's expectations for success in science and on values associated with a particular task (Figure 1).

EFA revealed two factors in our study: Factor 1 - Temporal comparison/Social persuasion, and Factor 2 - Dimensional comparison/Physiological state. Three variables of the first factor (Temporal comparison/Social persuasion) are based on SSC temporal comparison for a long time: "I am good at working out", "I learn things quickly", "I usually do well". One variable ("My teacher tells me I am good at physics/chemistry/ biology") describes social persuasions and is a theoretically justified source of self-efficacy. EFA revealed that SSC is better predicted by temporal comparison, whereas SSE - by social persuasions. Other scholars (Sheldrake, 2016; Jansen, Scherer, \& Schroeders, 2015) disclose various sources of SSC and SSE based not only on EVT. There is evidence that SSC is better predicted by received praise, current grades, and interest in science, whereas 
SSE - by inquiry-based learning opportunities, and by current grades and perceived utility of science (Sheldrake, 2016; Jansen, Scherer, \& Schroeders, 2015).

In this study, we examined how different components (SSC and SSE) of self-confidence in science were related to motivation for learning science. We revealed that the correlation coefficients between SSE (social persuasions) and intrinsic motivation variables were lower than the coefficients between SSC (temporal comparison) and intrinsic motivation variables. This conclusion was confirmed statistically (Table 3). This result also confirmed previous evidence: "When educational aspirations and student motivation are of interest, self-concept serves as a meaningful predictor. When the focus of the study lies in academic achievement, students' self-efficacy is more appropriate" (Jansen et al., 2015, 22). Our findings confirm the conclusions of other researchers stating that an individual and positive feedback is an effective way to foster SSE and motivation for learning (O’Mara, Marsh, Craven, \& Debus, 2006; Nagengast, \& Marsh, 2014; Usta, 2017; Zheng et al., 2018).

Our study has two main limitations. The first limitation is that TIMSS data may be attributed to the specific achievements of the students of the country. Lithuania is not a country showing high performance in TIMSS 2015. Lay et al. (2013) drew a comparison between a high performing country as Singapore with not so high performing country as Malaysia for mathematics and science achievements in TIMSS 2007. Scholars reveal that "Singaporean students have higher expectancy value towards science and also result in higher science achievement" (Lay et al., 2013, 109). It is likely that the findings of self-confidence in science and motivation for learning science should be varied following a study with another country's database.

The second limitation lies in the fact that we did not investigate the mastery experience and vicarious experience, and their relationship with motivation for learning science (Picture 1). There is evidence from other researches that significant correlations exist between mastery experiences, vicarious experiences, social persuasions, physiological arousal, and self-efficacy. "Only mastery experiences significantly predicted science self-efficacy” (Britner \& Pajares, 2006, 485). It would be relevant to investigate how mastery experience and vicarious experience are related to students' intrinsic motivation for learning science and subjective task values.

Future investigations should extend this research to the exploration of self-confidence in science and motivation for learning science in the light of another EVT component subjective task values - and its components: attainment value, intrinsic value, utility value, and cost value. In the scholarly literature, it is proven that the interaction between expectancy and task value beliefs will determine the achievement-related behaviours (Lay et al., 2013). It would be relevant to investigate the relationship between a high task value belief and intrinsic motivation for learning science. It remains unclear what different subjective task-related values (attainment, intrinsic value, utility value, and cost) cause extrinsic and intrinsic motivation for learning sciences of school students. 


\section{Conclusions}

The concept of motivation explains different psychological theories. The socio-cognitive view based on expectancy-value theory of motivation. According to expectancy-value theory, the expectation of learners for success in science depends on self-confidence. The phenomenon of self-confidence can be expanded according to various fields of activity. Academic self-confidence reveals as academic self-concept and academic self-efficacy. Self-confidence in a science construct can be expanded according to the time line: past, present, and future. Science self-concept describes self-confidence based on past experiences (integrating historical experiences), whereas science self-confidence at present. Meanwhile, science self-efficacy is based on self-confidence for future attainment.

The research performed on the basis of TIMSS 2015 data from Lithuania allows maintaining that SSC is better correlated by temporal comparison, whereas SSE - by social persuasions. The correlation coefficients between SSE (social persuasions) and intrinsic motivation variables were lower than the coefficients between SSC (temporal comparison) and intrinsic motivation variables.

The data based on different subscales (SCB, SCC, SCP) of Students Confident in Science scale confirmed that there were not several alternatives to models of confidence in science for different subjects: biology, chemistry, physics.

\section{References}

Akilli, M. (2015). Regression levels of Selected Affective Factors on Science Achievement: A Structural Equation Model with TIMSS 2011 Data. Online Submission, 19, 1-16.

Bandura, A. (1994). Self-efficacy. In V. S. Ramachaudran. (Ed.). Encyclopedia of Human Behavior.

New York: Academic Press. (Reprinted in H. Friedman (Ed.), Encyclopedia of Mental Health. (1998), 4, 71-81. San Diego: Academic Press.

Bandura, A. (1997). Self-Efficacy: The Exercise of Control. New York: Freeman.

Bøe, M. V., \& Henriksen, E. K. (2015). Expectancy-Value Perspectives on Choice of Science and Technology Education in Late-Modern Societies. In E. K. Henriksen, J. Dillon, \& J. Ryder (Eds.), Understanding Student Participation and Choice in Science and Technology Education (pp. 17-29). Dordrecht: Springer. Retrieved from: http://dx.doi.org/10.1007/978-94-007-7793$4 \_2$

Bong, M., \& Skaalvik, E. M. (2003). Academic Self-Concept and Self-Efficacy: How Different Are

They Really? Educational Psychology Review, 15, 1-40. doi:10.1023/A:1021302408382

Bong, M., \& Clark, R. E. (1999). Comparison Between Self-Concept and Self-Efficacy in Academic Motivation Research. Educational Psychology Review, 34, 139-154. 
Chen, J. A., \& Tutwiler, M. S. (2017). Implicit Theories of Ability and Self-Efficacy: Testing Alternative Social Cognitive Models to Science Motivation. Zeitschrift Für Psychologie, 225(2), 127-136. doi:10.1027/2151-2604/a000289

Eccles, J. (1983). Expectancies, values, and academic behaviors. In J. T. Spence. (Ed.). Achievement and Achievement Motives: Psychological and Sociological Approaches (pp. 75-146). San Francisco, CA: W. H. Freeman.

Eccles, J. S. (2009). Who am I and What am I Going to Do with My Life? Educational Psychologist, 44, 78-89.

Field, A. (2000). Discovering Statistics using SPSS for Windows. London - Thousand Oaks - New Delhi: Sage Publications.

Jansen, M., Scherer, R., \& Schroeders, U. (2015). Students' Self-Concept and Self-Efficacy in the Sciences: Differential Relations to Antecedents and Educational Outcomes. Contemporary Educational Psychology, 41, 13-24. doi:http:// dx.doi.org/10.1016/j.cedpsych.2014.11.002 Jansen, M., Schroeders, U., \& Ludtke, O. (2014). Academic Self-Concept in Science: Multidimensionality, Relations to Achievement Measures, and Gender Differences. Learning and Individual Differences, 30, 11-21. doi: 10.1016/j.lindif.2013.12.003

Keller, J. (1987). Development and Use of the ARCS Model of Instructional Design. Journal of Instructional Development, 10(3), 2-10.

Kim, J. (2004). Educational Psychology. Seoul: Seohyun-sa.

Lay, Y., Ng, K., \& Chong, P. (2015). Analyzing Affective Factors Related to Eighth Grade Learners' Science and Mathematics Achievement in TIMSS 2007. Asia-Pacific Education Researcher (Springer Science \& Business Media B.V.), 24(1), 103-110. doi:10.1007/s40299-013-0163-0

Marsh, H. W., \& Craven, R. G. (2006). Reciprocal Effects of Self-Concept and Performance from a Multidimensional Perspective. Beyond Seductive Pleasure and Unidimensional Perspectives. Perspectives on Psychological Science, 1(2), 133-163. doi:10.1111/j.1745-6916.2006.00010.x

Martin, M. O., Mullis, I. V. S., Hooper, M., Yin, L., Foy, P., \& Palazzo, L. (2016). Creating and Interpreting the TIMSS 2015 Context Questionnaire Scales. In M. O. Martin, I. V. S. Mullis, \& M. Hooper (Eds.). Methods and Procedures in TIMSS 2015 (pp.15.1-15.312). Retrieved from: Boston College, TIMSS \& PIRLS International Study Centre website: http://timss.bc.edu/ publications/timss/2015-methods/chapter-15.html

Moller, J., \& Marsh, H. W. (2013). Dimensional Comparison Theory. Psychological Review, 120, 544-560. doi:10.1037/a0032459

Myeong-Hee Shin1. (2018). Effects of Project-Based Learning on Students' Motivation and SelfEfficacy. English Teaching, 73(1), 95-114. doi:10.15858/engtea.73.1.201803.95

Nagengast, B., \& Marsh, H.W. (2012). Big Fish in Little Ponds Aspire More: Mediation and Cross-Cultural Generalizability of School-Average Ability Effects on Self-Concept and Career Aspirations in Science. Journal of Educational Psychology, 104, 1033-1053. doi:10.1037/ a0027697.

Nagengast, B., \& Marsh, H.W. (2014). Motivation and Engagement in Science Around the Globe: Testing Measurement Invariance with Multigroup Structural Equation Models Across 
57 Countries using PISA 2006. In L. Rutkowski, M. von Davier, \& D. Rutkowski. (Eds.). Handbook of International Large-Scale Assessment (pp. 317-344). Boca Raton, FL: CRC Press. Nagengast, B., Marsh, H. W., Scalas, L. F., Xu, M. K., Hau, K. T., \& Trautwein, U. (2011). Who Took the " $x$ " Out of Expectancy-Value Theory? A Psychological Mystery, a SubstantiveMethodological Synergy, and a Cross-National Generalization. Psychological Science, 22(8), 1058-1066.

Ng, K. T., Lay, Y. F., Areepattamannil, S., Treagust, D. F., \& Chandrasegaran, A. L. (2012). Relationship Between Affect and Achievement in Science and Mathematics in Malaysia and Singapore. Research in Science \& Technological Education, 30(3), 225-237.

O’Mara, A. I., Marsh, H. W., Craven, R. G., \& Debus, R. L. (2006). Do Self-Concept Interventions Make a Difference? A Synergistic Blend of Construct Validation and Meta-analysis. Educational Psychologist, 41, 181-206. doi:10.1027/s15326985ep4103_4

Osborne, J., Simon, S., \& Collins, S. (2003). Attitudes Towards Science: a Review of the Literature and Its Implications. International Journal of Science Education, 25, 1049-1079.

Pajares, F., Britner, S. L., \& Valiante, G. (2000). Relation Between Achievement Goals and Self-Beliefs of Middle School Students in Writing and Science. Contemporary Educational Psychology, 25, 406-422. doi:10.1006/ceps.1999.1027

Parker, P. D., Marsh, H. W., Ciarrochi, J., Marshall, S., \& Abduljabbar, A. S. (2014). Juxtaposing Math Self-Efficacy and Self-Concept as Predictors of Long-Term Achievement Outcomes. Educational Psychology, 34, 29-48. doi:10.1080/ 01443410.2013.797339

Pintrich, P. R. (2003). A Motivational Science Perspective on the Role of Student Motivation in Learning and Teaching Contexts. Journal of Educational Psychology, 95(4), 667-686.

Shavelson, R. J., Hubner, J. J., \& Stanton, G. C. (1976). Self-Concept: Validation of Construct Interpretations. Review of Educational Research, 46, 407-441. doi:10.3102/00346543046003407 Sheldrake, R. (2016). Students' Intentions Towards Studying Science at Upper-Secondary School: The Differential Effects of Under-Confidence and Over-Confidence. International Journal of Science Education, 38(8), 1256-1277.

Sheldrake, R., (2016). Confidence as Motivational Expressions of Interest, Utility, and Other Influences: Exploring Under-Confidence and Over-Confidence in Science Students at Secondary School. International Journal of Educational Research, 76, 50-65. doi: 10.1016/j. ijer.2015.12.001

Sheldrake, R., Mujtaba, T., \& Reiss, M. J. (2015). Students' Intentions to Study Non-Compulsory Mathematics: the Importance of How Good You Think You Are. British Educational Research Journal, 41(3), 462-488. Retrieved from: http://dx.doi.org/10.1002/berj.3150

Shin, M-H. (2018). Effects of Project-Based Learning on Students' Motivation and Self-Efficacy. English Teaching, 73(1), Spring 2018. doi: 10.15858/engtea.73.1.201803.95

Shumow, L., Schmidt, J. A., \& Zaleski, D. J. (2013). Multiple Perspectives on Student Learning, Engagement, and Motivation in High School Biology Labs. High School Journal, 96(3), 232-252. 
Skaalvik, E. M., \& Skaalvik, S. (2004). Self-Concept and Self-Efficacy: a Test of the Internal/ External Frame of Reference Model and Predictions of Subsequent Motivation and Achievement. Psychological Reports, 95, 1187-1202. doi:10.2466/ pr0.95.3f.1187-1202.

Trautwein, U., Marsh, H. W., Nagengast, B., Lüdtke, O., Nagy, G., \& Jonkmann, K. (2012). Probing For the Multiplicative Term in Modern Expectancy-Value Theory: A Latent Interaction Modeling Study. Journal of educational psychology, 104(3), 763-777.

Usher, E. L., \& Pajares, F. (2009). Sources of Self-Efficacy in Mathematics: a Validation Study.

Contemporary Educational Psychology, 34, 89-101. doi: 10.1016/j.cedpsych.2008.09.002

Usta, H. G. (2017). Examination of the Relationship between TEOG Score Transition (from

Basic to Secondary Education), Self-Confidence, Self-Efficacy and Motivation Level. Journal of Education and Practice, 8(6), 36-47.

Viljaranta, J., Tolvanen, A., Aunola, K., \& Nurmi, J.-E. (2014). The Developmental Dynamics

Between Interest, Self-Concept of Ability, and Academic Performance. Scandinavian Journal of Educational Research, 58(6), 734-756. http://dx.doi.org/10.1080/00313831.2014.904419

Wigfield, A., \& Eccles, J. S. (2000). Expectancy-Value Theory of Motivation. Contemporary Educational Psychology, 25, 68-81.

Wlodkowski, R. J. (1999). Enhancing Adult Motivation to Learn. San Francisco, CA: Jossey-Bass. Zheng, L., Dong, Y., Huang, R., Chang, C., \& Bhagat, K. K. (2018). Investigating the Interrelationships among Conceptions of, Approaches to, and Self-Efficacy in Learning Science. International Journal of Science Education, 40(2), 139-158.

Zimmerman, B. J., (2000). Self-Efficacy: An Essential Motive to Learn. Contemporary Educational Psychology, 25, 82-91.

\section{Mokinių pasitikèjimas savo gamtamokslinių dalykų gebejjimais ir vidinè gamtamokslinių dalykų mokymosi motyvacija: savivokos ir saviveiksmingumo aspektas}

Palmira Pečiuliauskienè

Vytauto Didžiojo universitetas, K. Donelaičio g. 58, 44248 Kaunas, palmira.peciuliauskiene@vdu.lt

\section{Santrauka}

Straipsnyje nagrinejjama Lietuvos mokinių, kurie dalyvavo tarptautiniame TIMSS 2015 tyrime, pasitikejjimas savo gamtamoksliniais gebejjimais ir vidinė gamtamokslinių dalykų mokymosi motyvacija. Tyrimo tikslas - atskleisti mokinių pasitikejimo savo gamtamoksliniais gebejjimais ir vidinès gamtamokslinių dalykų mokymosi motyvacijos sąsajas. Teorinis tyrimo pagrindas Lūkesčių-Verčių teorija (angl. Expectation-Values Theory - EVT). Tyrimas grindžiamas dviem 
esminiais šios teorijos komponentais: savivoka (angl. self-concept) ir saviveiksmingumu (angl. self-efficacy).

Tyrimo tikslui pasiekti buvo taikoma tiriamoji faktorinè analizè (angl. Exploratory Factor Analysis - EFA) ir koreliacinè analizè. EFA išryškino du esminius mokinių pasitikejjimo savo gamtamoksliais gebejjimais veiksnius: gamtamokslinių dalykų mokytojų žodiniai paskatinimai (angl. social persuasion) ir mokinių gamtamokslinių dalykų gebejjimų pokyčių įsivertinimas per laiką (angl. temporal comparison).

Koreliacinè analizè parodè, kad žemesni, tačiau statistiškai reikšmingi koreliacijos koeficientai nustatyti tarp visų mokinių vidinès mokymosi motyvacijos kintamųjų ir gamtamokslinių dalykų mokytojų žodinių paskatinimų. Aukštesni koreliacijos koeficientai nustatyti tarp visų mokinių vidinès gamtamokslinių dalykų mokymosi motyvacijos kintamųjų ir jų gamtamokslinių dalykų gebejjimų ịsivertinimo.

Esminiai žodžiai: pasitikejjimas gamtamokslinių dalyku gebẻjimais, gamtamokslinè savivoka, gamtamokslinis saviveiksmingumas, vidiné gamtamoksliniu dalyku mokymosi motyvacija.

Gauta 20200210 / Received 10022020

Priimta 20200413 / Accepted 13042020 